\title{
Strategic and tactical determinants for South African platinum-group- metals supply
}

\author{
J.E. McGill Centre for Mining Innovation, South Africa
}

\begin{abstract}
Global demand for platinum-group-metals (PGM) has supported the dominance of the Bushveld Complex in South Africa in global commodity supply. Presently $76.5 \%$ of the world's PGMs are supplied from South African mining operations on the Bushveld Complex. Historically the majority of supply originated from the geographically distinct western limb. However, through resource depletion, and increased mining depths on the west, alternative supply warrants consideration. Various tactical (immediate and short-run) requirements and equally important strategic (long-run) issues and objectives are used to assess the potential for competitive future supply being derived from the eastern limb.
\end{abstract}

\section{Introduction}

The mineral resources sector displays a careful balancing act between operation specific tactics designed to maximize shareholder returns; and overarching industry-related strategies employed by various entities including country governments, global interest groups, and multi-national head offices. This balancing act of short-term business tactics juxtaposed along-side long-run strategic intent of the extraction sector remains the exciting challenge for firms world-wide. One intriguing example of this relationship is the production of PGMs from the Bushveld Complex, South Africa.

The abundance of mineral deposits in South Africa is well known and resulted in the development landscape being dominated by mining, particularly the gold sector. The multiplier effect, whereby primary industries propagate related business, has lead to the sustained economic growth of South Africa. Seventy six percent of the world's PGMs are supplied from mining operations in South Africa's Bushveld Complex (Butler, 2011). The Bushveld Complex has geographically distinct western and eastern portions. Historically the majority of supply originated from the western limb due to the favourable platinum grade distribution, geographical proximity to existing power, transport, and water infrastructure, and human-resource availability from the nearby Gauteng Province. Through resource depletion and increased mining depth in the west, an alternative supply for these metals in the eastern limb of the Bushveld Complex may be advantageous.

As a result of significant legislative changes in South Africa and market demand drivers, the eastern limb now has the potential to provide significant future production. However, the South African minerals sector does not come without risks and constraints. This paper assesses strategic and tactical elements, resulting in a platform for policy related discussions, and investor considerations as to how South Africa should view the eastern limb resources if global competitiveness in PGM production is to be maintained long term.

\section{Assessment of strategic and tactical determinants for PGM supply}

The western and eastern limbs of the PGM-producing Bushveld Complex are geographically $300 \mathrm{~km}$ apart and exhibit distinct differences (Table 1). As mining on the western limb gets deeper, and consequently more expensive, a strategic choice is available to South African PGM producing firms. They can continue deep development on the western limb, move to open shallower mines in the eastern limb, or adopt a combination of both approaches. 
To investigate the viability of eastern limb resources, and reserves, three main issues require consideration. First, is continued investment in the global PGM sector warranted? If such investment is deemed necessary, then can this production occur in South Africa? Finally, if South Africa can support such development what factors allow for targeted eastern limb production? To assess these strategic issues, three levels of factors and associated determinants were critically evaluated (Table 2). Strategic elements are differentiated from tactical fundamentals as follows: Strategic elements are related to long-term goals that tackle overarching industry uncertainties and would impact the majority of industry participants equally; while tactical fundamentals relate to firm practices, with a short/medium-term focus, relating to gaining advantage, or success, over competitors. Over time these strategic and tactical determinants can however change relative to the overarching dynamic global environment (Deloitte, 2011).

Table 1 Summary of differences between the western and eastern limb of the Bushveld Complex

\begin{tabular}{|c|c|c|}
\hline Feature & West & East \\
\hline Geography & $\begin{array}{l}\text { Surface topography is flat facilitating } \\
\text { open-pits or vertical shafts to intersect } \\
\text { deeper horizons. }\end{array}$ & $\begin{array}{l}\text { Economic horizon outcrops on surface } \\
\text { within the topography, facilitating } \\
\text { declines. }\end{array}$ \\
\hline \multirow[t]{6}{*}{ Geology } & Strike length: $170 \mathrm{~km}$ & Strike length: $120 \mathrm{~km}$ \\
\hline & Dip: $9-25^{\circ}$ & Dip: $9-25^{\circ}$ \\
\hline & MR width: $60-90 \mathrm{~cm}$ & MR width: $100-300 \mathrm{~cm}$ \\
\hline & UG2 width: $65-110 \mathrm{~cm}$ & UG2 width: $80-120 \mathrm{~cm}$ \\
\hline & $\begin{array}{l}\text { Minor faulting, except in vicinity of the } \\
\text { Pilanesburg Alkaline Complex. }\end{array}$ & Faulting more prevalent. \\
\hline & Resource definition largely completed. & $\begin{array}{l}\text { Higher drilling densities required for } \\
\text { adequate resource definition. }\end{array}$ \\
\hline \multirow[t]{2}{*}{ Mining } & $\begin{array}{l}\text { Merensky Reef and UG2 reserves require } \\
\text { deeper stoping to extend existing } \\
\text { reserves. }\end{array}$ & $\begin{array}{l}\text { Shallower mining depths possible for } \\
\text { current Merensky Reef and UG2 reserves. }\end{array}$ \\
\hline & $\begin{array}{l}\text { UG2 is up to } 80 \mathrm{~cm} \text { thick resulting in over- } \\
\text { break during stoping. }\end{array}$ & $\begin{array}{l}\text { UG2 is } 80-120 \mathrm{~cm} \text { thick allowing mining } \\
\text { without much over-break. }\end{array}$ \\
\hline Processing & $\begin{array}{l}\text { Greater concentration of sulfides in the } \\
\text { Merensky Reef. }\end{array}$ & UG2 has more chromite. \\
\hline \multirow[t]{3}{*}{ Economics } & 4E basket more favorable & Chromite by-product credits \\
\hline & Merensky Reef grade $(3-9 \mathrm{~g} / \mathrm{t})$ & UG2 grade $(3-8 \mathrm{~g} / \mathrm{t})$ \\
\hline & $\begin{array}{l}\text { Lower Pt-Pd ratios, containing less } \\
\text { rhodium. }\end{array}$ & $\begin{array}{l}\text { Higher Pt-Pd ratios, containing more } \\
\text { rhodium. }\end{array}$ \\
\hline Infrastructure & $\begin{array}{l}\text { Extensive existing framework of power } \\
\text { and water supply, and road networks. }\end{array}$ & $\begin{array}{l}\text { Require significant new infrastructure } \\
\text { development, and water reticulation } \\
\text { services. }\end{array}$ \\
\hline
\end{tabular}


Table 2 Assessment Factors and strategic versus tactical determinants

\begin{tabular}{|c|c|c|}
\hline \multicolumn{2}{|l|}{ Factor } & \multirow{2}{*}{$\begin{array}{l}\text { Description } \\
\text { The long-run forecast of demand and supply dynamics, and } \\
\text { commodity prices, underpin a continued need for PGM } \\
\text { production. }\end{array}$} \\
\hline $\begin{array}{l}\text { Global PGM } \\
\text { sector }\end{array}$ & Strategic 1 & \\
\hline $\begin{array}{l}\text { National policy } \\
\text { framework }\end{array}$ & Strategic 2 & $\begin{array}{l}\text { Legislative environment supports the development of PGM } \\
\text { resources in South Africa. }\end{array}$ \\
\hline \multirow[t]{5}{*}{$\begin{array}{l}\text { Direct eastern } \\
\text { limb factors }\end{array}$} & Strategic 3 & $\begin{array}{l}\text { The eastern limb contains deposits of sufficient size, and } \\
\text { grade, to support mineral production. }\end{array}$ \\
\hline & Tactical 1 & $\begin{array}{l}\text { An eastern limb supply pipeline, comprising all phases of the } \\
\text { mineral resource value chain, is present. }\end{array}$ \\
\hline & Tactical 2 & $\begin{array}{l}\text { Initial mining of the eastern limb will be at shallow to } \\
\text { intermediate depths facilitating largely mechanized } \\
\text { operations that are cost effective and safe. }\end{array}$ \\
\hline & Tactical 3 & $\begin{array}{l}\text { The production of PGMs on the eastern limb is economically } \\
\text { competitive, relative to the continuation of western limb } \\
\text { production. }\end{array}$ \\
\hline & Tactical 4 & $\begin{array}{l}\text { Adequate power and water supply exists to support eastern } \\
\text { limb mine development. }\end{array}$ \\
\hline
\end{tabular}

2.1 Strategic determinant 1 - the long-run forecast of consumption and production dynamics, and commodity prices, underpin a continued need for global PGM production

Global consumption of PGMs is centred on autocatalysts, jewellery, industrial demand, and physical investment comprising both exchange traded funds and metal inventory (Butler, 2009). The short-term market prognosis is for an overall reduction in platinum demand. During 2009-2011 South African supply was depressed relative to pre-2008 levels due to safety breaches and labor strikes that forced production suspensions, and a weak exchange rate that resulted in unfavourable production costs. In the medium term, 2011-2015, supply will be sustained as prices will remain largely unchanged, as any changes in demand can be matched by changes in supply (Black, 2009). After 2015 it is expected that consumption will exceed production as a result of renewed future growth in emerging markets, tighter toxic emission controls, and commercialization of stationary fuel cell units used for residential heating and power (Steven Forrest Associates, 2009). Any long-term supply gap will be filled by either primary production or recycling.

Global demand trends for PGMs remain justified for the long-run and it is anticipated that supply will peak around 2014/2015 after which a supply gap could result in an overall PGM shortfall by 2029 (Black, 2009; Johnson Matthey, 2010). This gap would need to be satisfied through either primary production, or recycling. Therefore the need for future PGM production to sustain predicted demand is warranted.

\subsection{Strategic determinant 2 - the legislative environment supports the development of PGM resources in South Africa}

\subsubsection{Legislative environment}

Before April 30, 2004 the key minerals legislation in South Africa was the Minerals Act, No. 50 of 1991. Under this act the right to mine was vested in the holder of the mineral right. The Mineral and Petroleum Resources Development Act No 28, 2002 (MPRDA) came into effect on May 1, 2004 replacing the Minerals Act. Two of the principal requirements within this legislation are: (a) to ensure that the state becomes the 
custodian of the country's mineral wealth, and (b) that previously disadvantaged sectors of the population have greater access to the countries' inherent mineral wealth.

The first objective was achieved through the transfer of mineral rights from private mining companies to the state. During this time, mining companies could apply for, and receive, licenses granting them the right to mine. During the initial transitional phase mineral rights holders could convert "old order" rights into "new order" rights. The policy is termed "use it or lose it" and prevented companies with significant land tenures from occupying undeveloped resources. In this manner resources became available to other mining firms.

In order to be granted new order rights a proportion of currently held assets must be transferred to historically disadvantaged groups thereby fulfilling the second objective. Historically disadvantaged South Africans have to own a $26 \%$ attributable interest in mineral production by 2016 . This legislative requirement provided the incentive for mining companies to partner with black-owned businesses to ensure that compliance and redistribution occurs. By August 2010 the average black ownership of mining companies in all commodity sectors was $8 \%$ (Gqubule, 2010).

Finally, royalties are imposed on all transfers of mineral resources on, or after, March 1, 2010 (van der Zwan, 2010). The royalty rates are based on net profit, and will not exceed $5 \%$ for refined mineral resources, and $7 \%$ for unrefined mineral resources. It is still too early to consider impacts of the royalty legislation on the platinum sector. Development of the varied minerals related legislation has been a long process and cumulatively represents ongoing efforts to improve equitability and economic benefits to the entire South African population

Mine nationalization remains a contentious and worrisome variable in the future landscape of the South African mining sector. This policy proposal is currently under review by the ruling African National Congress (ANC) party leadership and strongly opposed by the mining ministry. It can be argued that the current situation is in fact the hybrid approach where the government ensures State involvement through ownership, and does gain through the Mineral and Petroleum Resources Development Act, firm's income taxes, and mining royalty collection. Also the government has formed a state owned mining company: "African Exploration Mining Finance Corporation" which focuses on the exploration and development of strategic minerals.

All operators in the Bushveld must demonstrate equal legislative compliance. Currently exploitation of loopholes in the mineral legislation has created uncertainty over property rights, and security of tenure. This research indicates that with $30 \%$ of the eastern Bushveld available to be drilled, that these properties would potentially be in the DMR's processing pipeline and therefore subject to similar adjudication and associated uncertainty. Any future changes regarding issues of nationalization, or the development of state-owned-enterprises will impact all mines equally, unless specific "strategic" sectors are targeted for up and down stream development linkages (Jourdan, 2010). Currently the entire mining sector is on hold for outcomes from nationalization policy discussions, and a formal economic policy being formulated for 2012 . This overall political uncertainly has impacted South Africa's global investment risk profile, which would have a ripple effect on production economics and the ultimate profitability of operating mines on the eastern limb of the Bushveld.

\subsection{Strategic determinant 3 - the eastern limb contains deposits of sufficient size, and grade, to support mineral production}

Platinum group metals can be found in a variety of geological settings, but the only PGM deposits presently of economic importance are those associated with mafic or ultramafic rocks (Cawthorn et al., 2005). The Bushveld Complex is the most economically significant layered intrusion in the world. The deposit extends approximately $450 \mathrm{~km}$ east-west, and reaches a maximum thickness of $9 \mathrm{~km}$ (Naldrett, 2004). The total strike length of the Merensky Reef and UG2 is $170 \mathrm{~km}$ on the western limb versus $120 \mathrm{~km}$ on the eastern limb. PGM resources on the western limb consider mining to a depth of $2 \mathrm{~km}$ as the mineable horizons are continuous down dip. 
The principal PGM horizons, or reefs, are situated in the upper critical zone of the Rustenburg Layered Sequence. The Upper Group 2 (UG2) is associated with chromite layers, and overlying this is the Merensky Reef. The reefs have great lateral continuity, but there are also localized geological differences between these horizons on the different limbs of the complex (Cawthorn et al., 2005). The vertical separation between these two economic layers varies from $4 \mathrm{~m}$ to $400 \mathrm{~m}$ (Singh et al., 2005).

Overall the grade distribution between the western and eastern limbs of the Bushveld Complex is fairly similar with grades between 3-9 g/t. Of all the Bushveld operations 15 currently exploit the Merensky Reef, while 22 mine the UG2, with the greater number of current operations being located on the western limb (Figure 1 and 2). To compare the west and east limb deposits, grade and resource size were plotted for both the Merensky Reef and UG2. Merensky Reef resources have a fairly wide grade range $(3-8 \mathrm{~g} / \mathrm{t})$ and are mostly less than $100 \mathrm{Mt}$. UG2 operations exhibit a narrower grade range (3-6 g/t) than the Merensky Reef and a wide range of deposit sizes. The larger deposit size and more consistent grade profile, enhancing processing, make UG2 targets better than Merensky Reef targets. Currently there are marginally more resource tonnes on the western limb when compared with the eastern limb. This is attributed to the greater degree of delineation on the western limb. Due to the overall geological similarity, between the two limbs, it is inferred that with increased delineation the eastern limb contains deposits of sufficient size, and grade, to support mineral production.

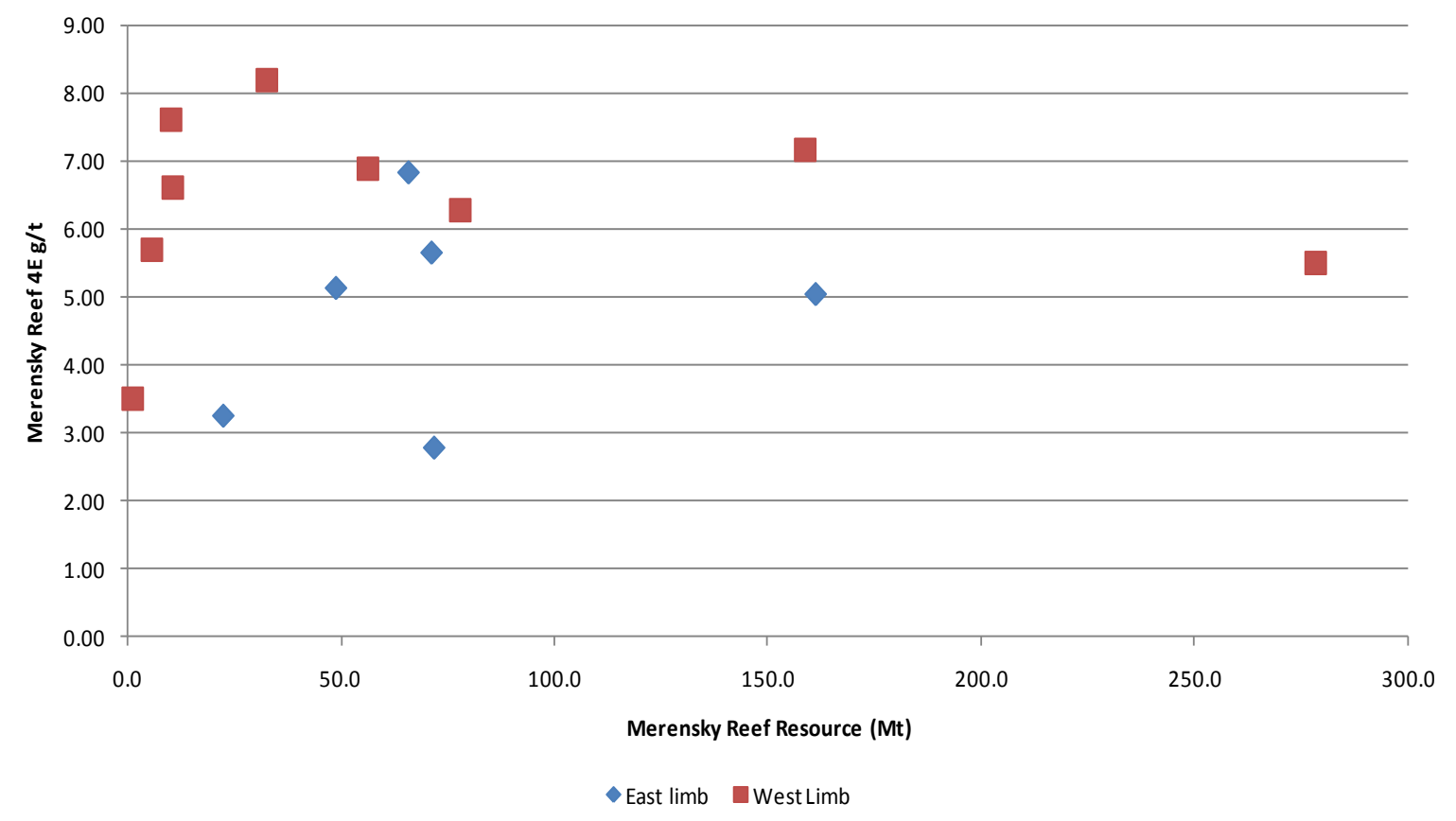

Figure 1 Relationship between grade (4E g/t) and Resource tonnes for the Merensky Reef from both the western and eastern limbs. Merensky Reef deposits tend to be somewhat higher grade than those on the eastern limb though there is a broad degree of overlap. The size of the deposits is probably similar. The lack of extremely large eastern limb deposits may be due to less delineation drilling. 


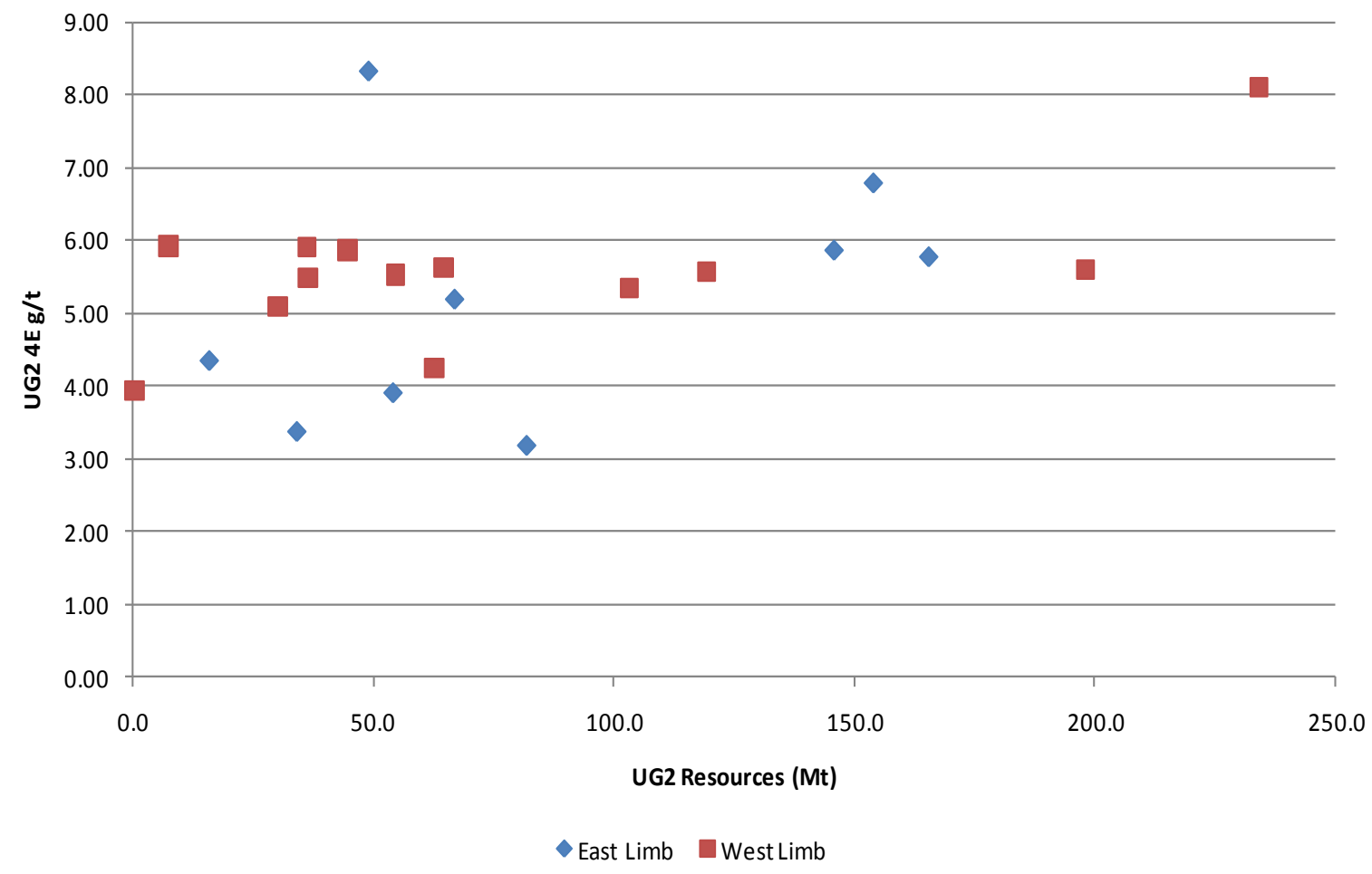

Figure 2 Relationship between grade (4E g/t) and Resource tonnes for the UG2 in both western and eastern limb deposits. The eastern limb deposits compare favourably in terms of both grade and tonnage with those of the western limb and there is a suggestion of slightly higher grade deposits on the eastern limb.

\subsection{Tactical determinant 1 - the eastern limb supply pipeline, comprising all phases of the mineral resource value chain, is currently present}

The discovery of new low cost deposits and/or the exhaustion of old deposits can cause the geographic location of competitive deposits to shift over time. For the eastern limb to become the future for Bushveld Complex production a pipeline of developments from exploration through feasibility to full production is required. Firms realize the importance of production replacement to satisfy demand growth. All current Bushveld producers and developers (initial exploration through feasibility and construction) were determined relative to locality (Table 3 ).

The data indicate that a healthy platinum production pipeline exists in South Africa. The total number of projects increased slightly between 2006 (during the commodity boom) and 2010 (post global economic downturn) but a shift in distribution has occurred. Exploration, advanced exploration and pre-feasibility stage projects are more prevalent (most started in 2008-2009) than late-stage projects. Three feasibility stage projects were deferred until PGM price recoveries occurred. Tier one companies have interests on both the western and eastern limbs while smaller tier two and three operators tend to instead occupy niche positions on a specific limb. Currently the majority of exploration and development projects are located on the eastern limb, where both the UG2 and Merensky Reef are targeted. In addition the projects on the eastern limb tend to have greater resource tonnes than those on the western limb (Figure 3). The eastern limb therefore has a greater critical mass of resource tonnes available in the project pipeline than the western limb. 
Table 3 The number of projects in South Africa per development phase

\begin{tabular}{lccccc}
\hline Development phase & $\begin{array}{c}\text { Total projects } \\
\text { (2006) }\end{array}$ & $\begin{array}{c}\text { Total projects } \\
\mathbf{( 2 0 1 0 )}\end{array}$ & $\begin{array}{c}\text { West } \\
\mathbf{( 2 0 1 0 )}\end{array}$ & $\begin{array}{c}\text { North } \\
\mathbf{( 2 0 1 0 )}\end{array}$ & $\begin{array}{c}\text { East } \\
(\mathbf{2 0 1 0})\end{array}$ \\
\hline Initial Exploration & 18 & 20 & 6 & 5 & 9 \\
Advanced Expl. & 13 & 17 & 6 & 4 & 7 \\
Pre-feasibility & 7 & 9 & 2 & 5 & 2 \\
Feasibility & 9 & 6 & 0 & 1 & 5 \\
Construction & 6 & 3 & 2 & 0 & 1 \\
Sum & 53 & 55 & 16 & 15 & 24 \\
\hline
\end{tabular}

$\sim$ The northern limb focuses on exploitation of the shallower Platreef. Platreef is not present on the western or eastern limbs. Northern limb project data has only been included for completeness.

Resource definition is largely completed on the western limb, while on the eastern limb approximately $70 \%$ of the targets have been delineated (D. Kershaw, 2010, written comm.). Drilling costs exceed ZAR 5 million per borehole in some western limb projects. Thus, delineating shallower east limb resources may be financially more attractive. 3D seismic analysis and remote sensing techniques to define targets prior to drilling on the western limb have supported accurate ore body delineation and assisted in mine planning and it is anticipated that these technologies can be directly applied in the east due to similar geology.

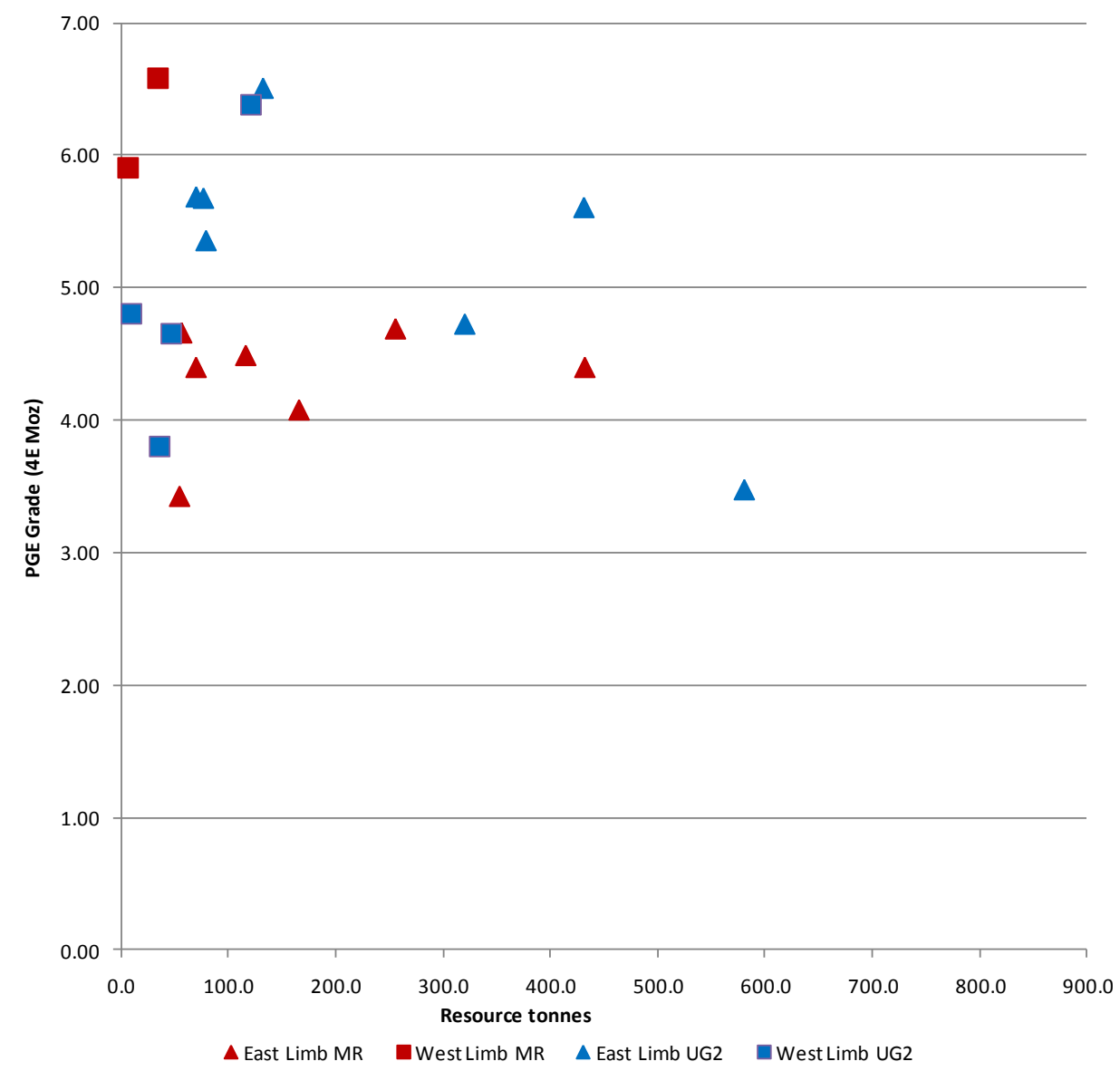

Figure 3 Locality and reef targeted by the projects in the pipeline, relative to grade and resource tonnes. Note that the resource figures for all of these projects may increase with continued exploration/delineation. 
Mining seeks to balance interdependent factors related to the rate of production, cost, and average grade, with the primary objective of seeking profitability within a safe operating environment. Narrow-reef mining methods employed in the Bushveld platinum mines were adapted from the Witwatersrand gold mines. Traditionally, the main horizon mined has been the Merensky Reef. Advances in metallurgical practices have permitted economic mining of the UG2 horizon since the 1980s (Cramer et al., 2004). Although the UG2 has lower PGM grades and an overall lower platinum/palladium ratio compared with the Merensky Reef, production from the UG2 has boosted revenues and extended mine life at many operations.

\subsubsection{Mine depth}

In South Africa shallow mining occurs at depths less than $900 \mathrm{~m}$ below surface and intermediate mining depths extend to approximately $1,500 \mathrm{~m}$ below surface. Deep mining is considered between 1,500 $\mathrm{m}$ and $2,800 \mathrm{~m}$ below surface; ultra-deep mining encompasses mining in excess of $2,800 \mathrm{~m}$ below surface. Since the majority of near surface PGM resources have been exploited on the western limb, future development there will require deeper, down dip extensions. The near-term eastern limb resources are shallower, and therefore easier to develop without complex, lengthy, and expensive, shaft requirements. Of the 31 South African PGM operations at the time of this study, $73 \%$ were solely underground operations, $6 \%$ were solely open-pit, 18\% were combined underground-open-pit operations, and $3 \%$ are tailings operations.

The topographical landscape will impact depth, and type of mine access on the eastern limb, and the resultant stope development. On the western limb, underground reef horizons are mostly accessed through shaft systems while in the eastern limb the Nebo Plateau escarpment edge facilitates decline access in some areas. Decline access development potential on the eastern limb is advantageous due to lower capital costs, and shorter development times when compared to shaft systems.

\subsubsection{Mechanization}

In South Africa underground mining methods are loosely referred to as being conventional or mechanized. However, the terms "conventional" and "mechanized" vary greatly depending upon deposit type, equipment used, mineral commodity, and traditional acceptance within a geographical region (for example, sublevel stoping, end-slicing, long-hole stoping, and vertical slotting methods all refer to essentially the same mining method but can be classified as either conventional or nonconventional depending upon the direction of the sublevels and cross-cuts). In the South African PGM mining context a suite of methods ranging from labor intensive breast longitudinal stoping, using handheld pneumatic drills ("conventional" in this context), to fully mechanized room-and-pillar operations, where each part of the mining cycle is undertaken using mechanized equipment is utilized. Various intermediate combinations of these two endmembers are also implemented. Overall, levels of automation are currently negligible on South African PGM mines and remain the focus of research and development initiatives.

Operators on each limb currently employ different mining methods though there is an overall overlap in mining techniques. The western limb favours the hybrid approach of mechanical tramming and conventional stope mining, while on the eastern limb bord-and-pillar is also utilized (Table 4). This difference is attributed to the shallower mining depth on the eastern limb that allows for the larger stope spans required for bord-and-pillar. Of the six newest mines (three on each limb (Black, 2009)) two are surface operations, one on the eastern limb employs bord-and-pillar, and three comprise hybrid, mining methods. Hybrid mining methods take advantage of faster and safer mechanized development, as well as the low dilution factors and higher shaft head grades that conventional stoping provides. 
Table 4 Principal PGM mining methods on western and eastern limb underground PGM operations

\begin{tabular}{llcc}
\hline & Mining Method & $\begin{array}{c}\text { Total } \\
\text { underground }\end{array}$ & West \\
\hline Underground & $\begin{array}{l}\text { Mechanized - Bord and Pillar using ultra low } \\
\text { profile machinery }\end{array}$ & $26 \%$ & 4 \\
& $\begin{array}{l}\text { Hybrid - mechanized tramming using load haul } \\
\text { dumpers (LHD's) and conveyors, and } \\
\text { conventional stope mining }\end{array}$ & $48 \%$ & 10 \\
& $\begin{array}{l}\text { Conventional - hand drilled and blasted material } \\
\text { removed from stope via box-holes using scrapers } \\
\text { and transported via rail hoppers }\end{array}$ & $26 \%$ & 3 \\
\hline
\end{tabular}

\subsubsection{Cost effectiveness}

Total mine ownership costs are comprised of capital expenditures, associated depreciation, and operating cash costs. Capital costs were not included in the scope of this analysis and should be considered in any detailed analyses. South African mining companies do not make in-stope operating mining costs available in the public domain and are particularly nervous about providing this data. Average direct mining cost ranges, per mining method, were combined from two confidential industry sources where in-stope mining costs were calculated the same, eliminating calculation variation from these ranges (Table 5).

Table 5 Comparison of Bushveld USD mining costs per mining method

\begin{tabular}{lccc}
\hline Mining Method & \multicolumn{3}{c}{ Direct (in-stope) mining costs (range) } \\
& $\mathbf{\$} / \mathbf{m}^{\mathbf{2}}$ mined & $\mathbf{\$} /$ tonne mined & \$/Equiv. reef oz \\
Conventional & $643-357$ & $50-92$ & $857-1,643$ \\
Hybrid & $472-542$ & $57-93$ & $1114-1,643$ \\
Mechanised & $257-414$ & $39-42$ & $886-1,000$ \\
Open-pit & & $9-14$ & $357-428$ \\
\hline
\end{tabular}

The cheapest mining method remains open pit operations, where no expensive stope development and support is required. Of the underground mining methods bulk mechanized mining methods are cheaper than conventional or hybrid approaches both of which include a greater labour component. If the eastern limb continues to support a greater degree of mechanization than the western limb, through shallower mining depths, mining should be able to promote positive margins on the eastern limb. Adoption of greater mechanization will be advantageous for eastern limb operations, but this would require an improved mechanized learning culture by the operations.

\subsubsection{Safety}

Mine health and safety issues are of the highest priority to both operators and the primary government regulator in South Africa: the Department of Mineral Resources (DMR). The DMR is focused on seeking ways to reduce the number and frequency of lost-time mining injuries and fatalities, as entire shaft closures are now enforced when fatalities occur. Due to varying levels of data transparency between the Bushveld operators an indication of western limb versus eastern limb safety levels was obtained from reported Anglo Platinum data for all operations (100\% owned/managed shafts and joint ventures) (15 operations in total, representing $50 \%$ of all Bushveld operations). In 2009 there was one fatality per four million tonnes broken on the eastern limb, while on the western limb one fatality occurred for every 3.3 million tonnes broken. In 
terms of fatality classification of all reported fatalities $41 \%$ of fatalities on the eastern limb were due to fallof-ground and $12 \%$ to powered haulage, while on the western limb $38 \%$ of fatalities were due to fall-ofground and $19 \%$ to powered haulage. The fewer number of operations, and the shallower average mining depth, on the eastern limb compared to the western limb contributes to the resultant lower accident rates, but fall-of-ground rates are slightly higher on the eastern limb. This should be recognized and new operations should pay particular attention to the fatality classification through correct rock support standards and implementation.

\subsection{Tactical determinant 3 - the production of PGMs on the eastern limb is economically competitive, relative to the continuation of western limb production}

South African PGM production has steadily increased over the past 30 years to its current level of 150 tons per year (Figure 4). Three main phases of increasing production rates are: 1981-1993 (apartheid era), 1993-2001 (post-apartheid growth), and 2001-2007 (significant commodity demand fuelled by global growth).

In South Africa PGM production is dominated by a limited number of firms. To distinguish between the producers within the market space companies are divided into tiers based on firm size, as determined by market-capitalization. The different companies, occupying different tier positions, also encompass different roles in the supply process: juniors tend to specialize in exploration and deposit delineation, midcaps produce ore but have no refining capacity while larger companies consider a broad based approach to PGM production. Ownership and market organization is complicated as companies contribute on operating agreements, or in joint venture partnerships, empowerment holdings or pooling and sharing agreements (Figure 5). These relationships are a result of major companies wanting to secure refinery feedstock, enhance corporate strategy and achieve black economic empowerment compliance (Jacobs, 2003).

While overall South African production has increased over time, the distribution of market share between the tier one producers has also shifted over time. The federal policy requirement to use mineral reserves, rather than hold onto them, has allowed a variety of participants to enter the sector, underpinning the redistribution (Figure 6). For instance, Anglo Platinum's contribution was consistently around 50\% until 2003 when the impact of redistribution through joint ventures and new entrants, as a result of legislative transformation, became clear. Impala Platinum and Lonmin market shares converge around $22 \%$ each. In 1996 and 2003 merger attempts between Impala and Lonmin were overturned by competition authorities. 


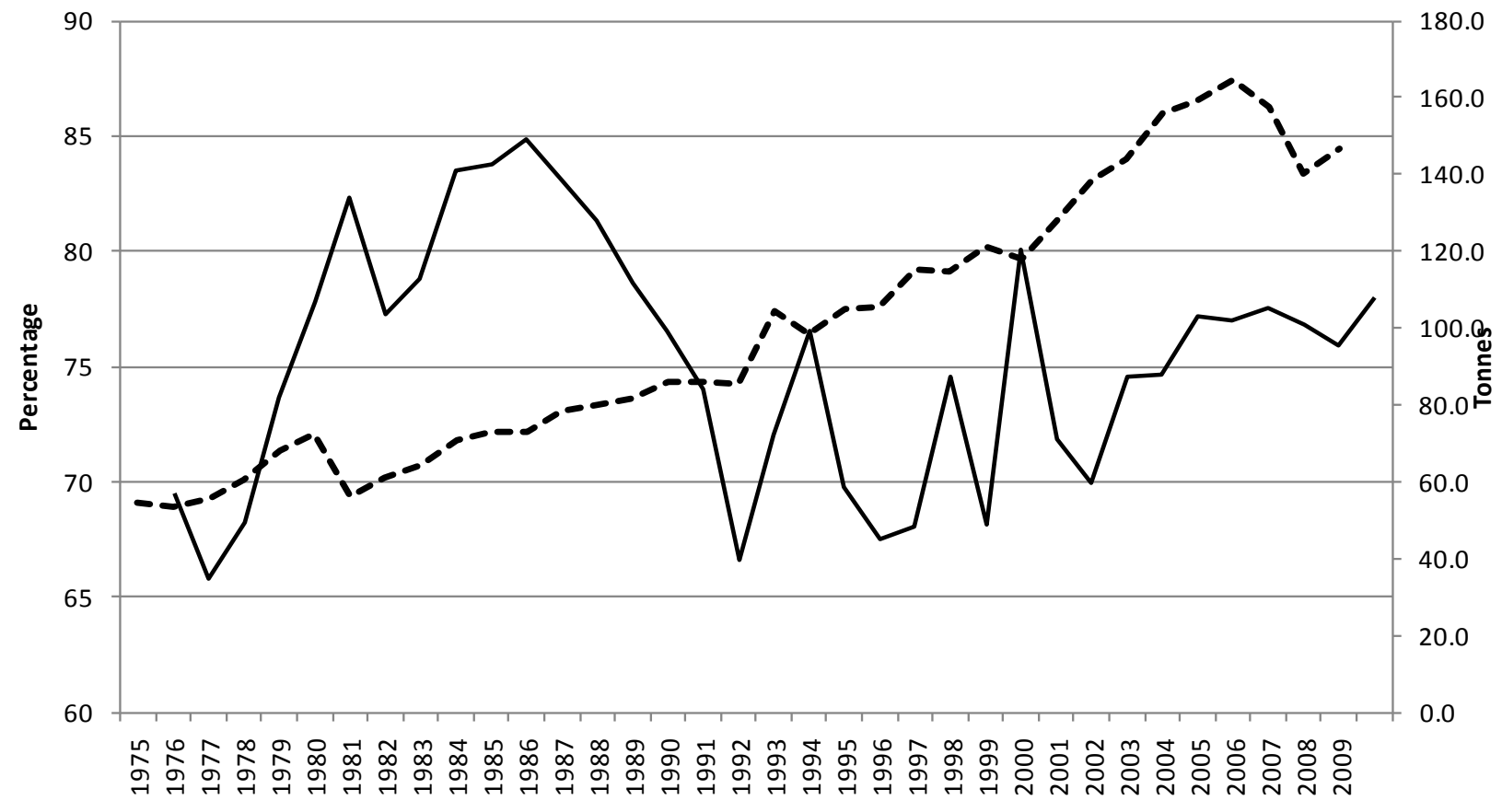

\% South Africa Market Share _ - - South Africa Production

Figure 4 Total South African PGM production and associated market share (1975-2009)

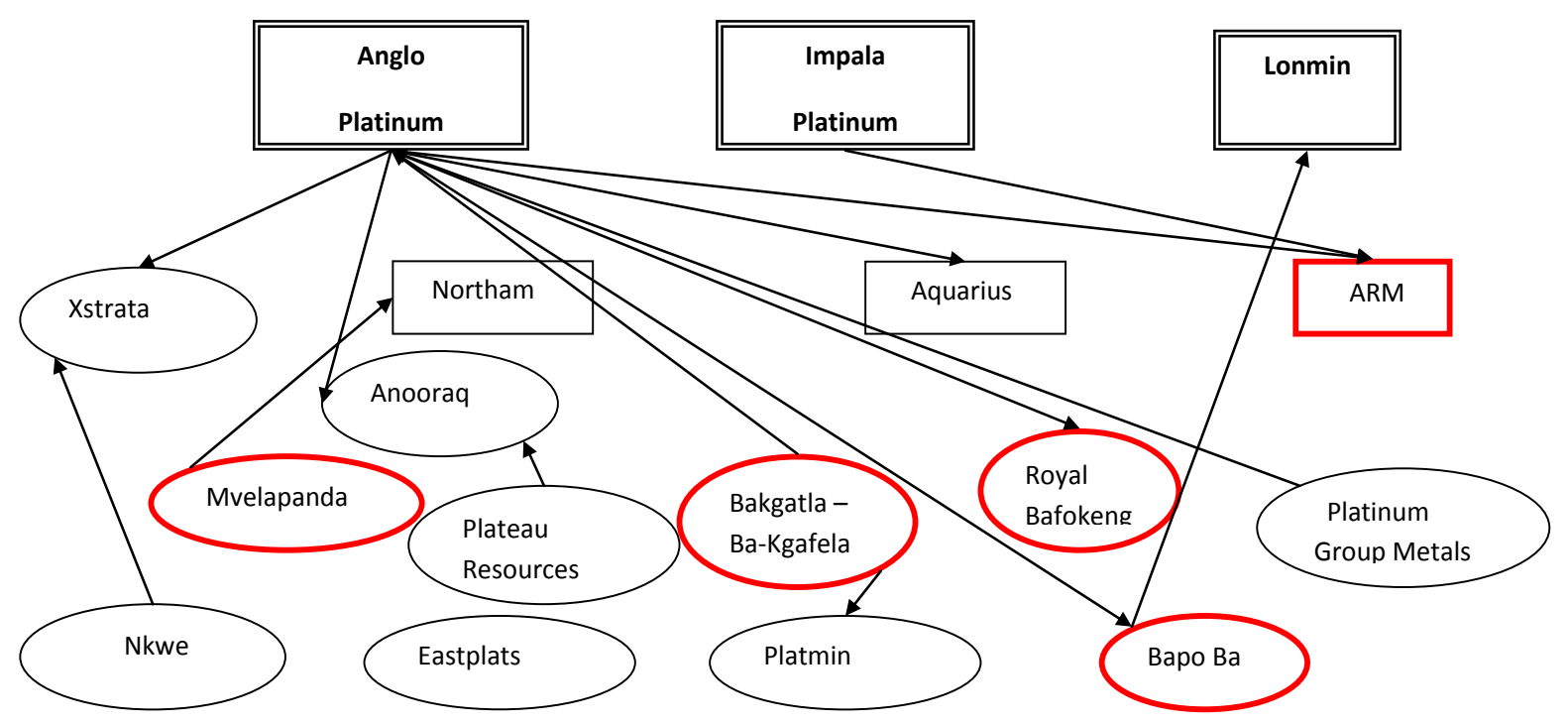

Figure 5 Spider diagram representing the relationship between key producers in the South African PGM sector, with the black empowered companies shown in red 


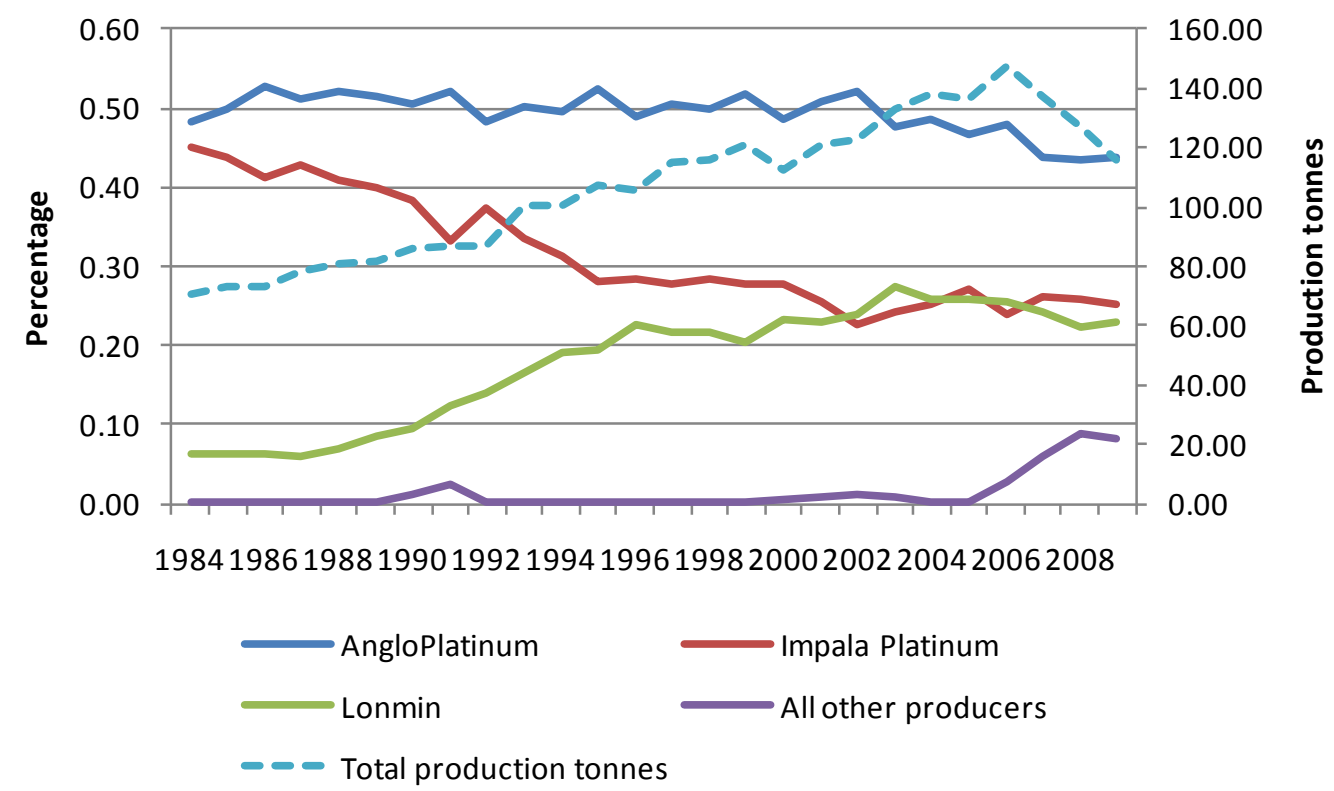

Figure 6 Market shares of key South African PGM producers relative to annual production tonnes (1984-2009)

\subsubsection{Low overall cash-costs}

Is it cheaper to mine on the eastern limb compared with the western limb? No clear distinction occurs with current eastern limb operations occupying places both at the high and low end of the cumulative cost curve (Figure 7). However, an average total $4 \mathrm{E}$ cash cost comparison reveals that presently the eastern limb operations are $\$ 100 / 0 z$ more expensive when compared with the west limb (Table 6). Presently, significantly more production ounces are derived from the western limb versus the eastern $\operatorname{limb}(6,700 \mathrm{oz}$ versus 2,600 oz) - but this analysis did exclude certain smaller non-listed eastern limb operations that have only recently came online (e.g. Anooraq). More resource ounces available for development on the eastern limb than the western limb bodes well for future development as these should be lower cost ounces than those already being produced due to increased prevalence of bulk mechanized mining methods.

Table 6 Comparison of average and ranges for western and eastern limb 4E cash costs

\begin{tabular}{lcc}
\hline & West & East \\
\hline Average (US\$/oz) & 1,264 & 1,355 \\
Range (US\$/oz) & $638-1,661$ & $696-2,575$ \\
\hline
\end{tabular}




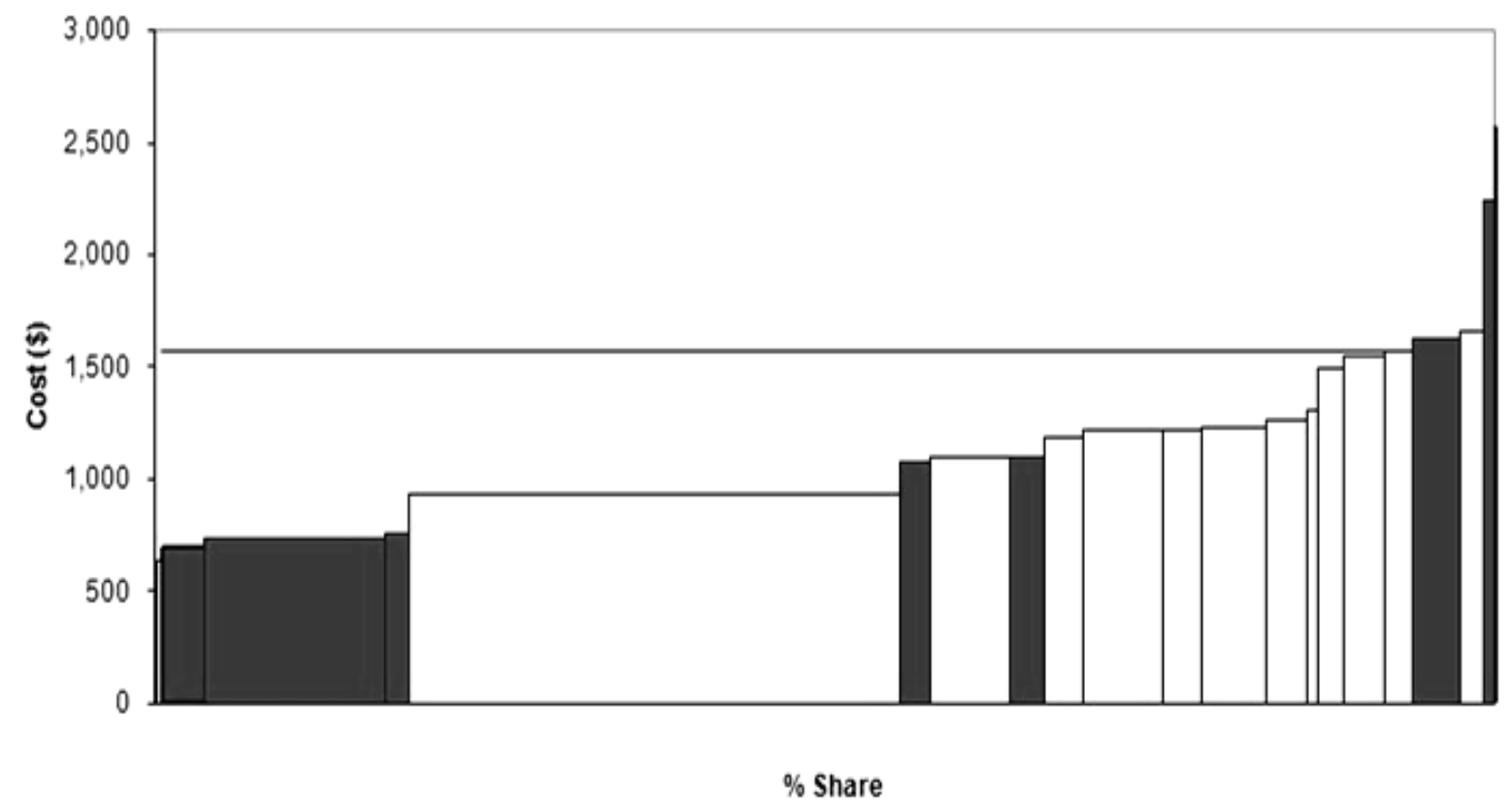

Figure 7 Cumulative cost curve for all Bushveld PGM operations. Western limb operations are white bars, while the eastern limb operations are represented by solid rectangles.

\subsubsection{Positive metal basket price}

The UG2 contains $8 \%$ - 9\% rhodium versus only $4 \%$ in the Merensky Reef. This implies that $10 \%$ of metal mined from the UG2 currently obtains prices with an average of US\$2247.83/oz. The profit margin associated with this is therefore very attractive and therefore would make the UG2 a more attractive source. However in the current east limb project pipeline only one project is specifically targeting only the UG2. The western limb benefits from a higher platinum content compared to the eastern limb (Figure 8). The relative price mix of the metals comprising the revenue basket will dictate which limb is more financially attractive in terms of metals content.

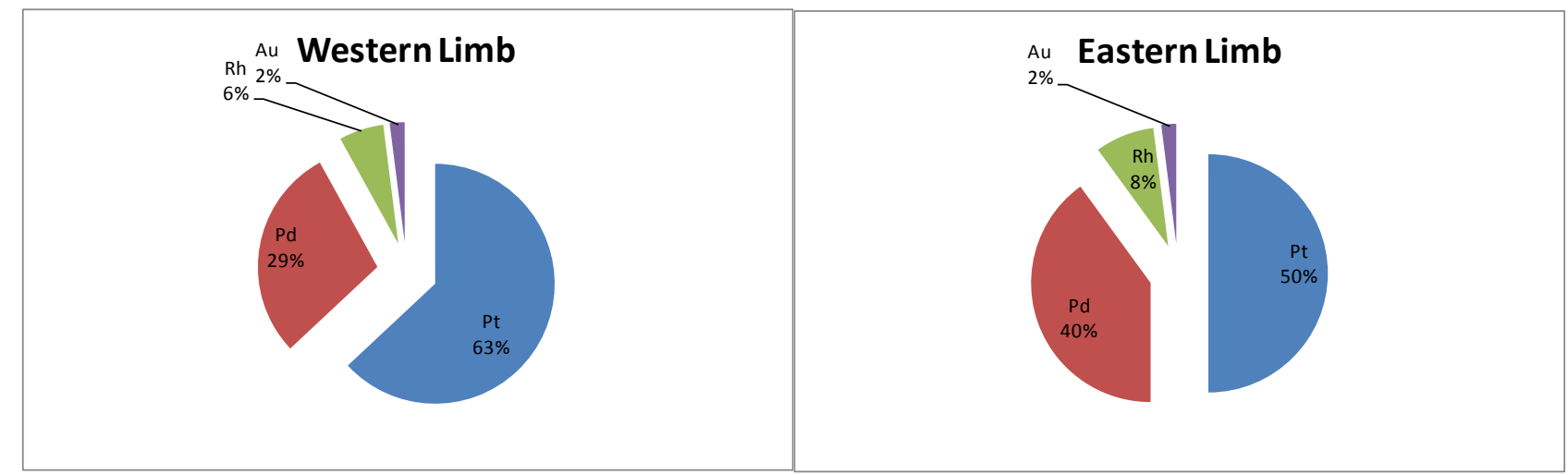

Figure 8 Composition of 4E basket on western and eastern limbs (Cramer, 2001)

\subsection{Tactical determinant 4 - adequate infrastructure (power and water supply) exists to support mine development on the eastern limb}

Development timing, power supply, and water availability are important factors considered for development of eastern versus western limb reserves. The ability to develop declines in preference to shaft systems for some projects on the eastern limb implies shorter development lead times. A new shaft would require effectively seven years while a decline could take approximately five years. Therefore, shorter lead 
times to development could favour eastern limb projects, which need to come on-line by 2015 to satisfy the forecast supply gap.

Subsequent to the power shortages of 2008, power supply remains a consideration for operations on both the limbs of the Bushveld where on average the cost of electricity is $12 \%$ of total working cost. Currently there appears to be sufficient power to satisfy current demand throughout the Bushveld. However, industry has serious concerns for future loads as a result of more mining operations. As a result of Eskom's recapitalization program, two new coal-fired power stations are being constructed and the "Platinum Basin initiative" has provided a 400kV transmission line and three new substations to serve the greater Bushveld Complex geographic area.

Water resources are scarce on the eastern limb. The main governmental priority throughout the Bushveld region remains the provision of water to the local communities. The new Lebalelo water distribution system and De Hoop Dam will aid significantly in providing water for both communities and eastern limb mine operations. Of the 21 total "water use license" applications for the De Hoop Dam 18 were from eastern limb current and future mines, while the remainder were from municipalities. Like electricity, current water resources can support the status quo. Future PGM mine development, especially on the eastern limb, would require additional access to water storage and reticulation.

There are currently differences with regards to power and electricity usage between existing western and eastern limb mines. However, capturing this data is difficult. Reporting standards, metrics and complexity are highly variable between the operators. Larger tier one companies are generally more transparent while other producers tend to report on a company rather than shaft basis. To obtain an indication of the scale of water and power usage between the two limbs, available data was allocated to the west versus east limbs (Table 7). Currently the eastern limb uses less electricity than the western limb. This is attributed to the shallower mining depths and the greater number of mine, concentrator and smelter complexes on the western limb. Currently the eastern limb uses marginally more water than the western limb. This is attributed to the Twickenham shaft where ore production is ramping up after mine development.

Table 7 Comparison of 2009 water and electricity usage on the western and eastern limbs (Glaister \& Mudd, 2010)

\begin{tabular}{lcc}
\hline 2009 & West & East \\
\hline Power $(\mathrm{MJ} /$ t ore $)$ & 524 & 346 \\
Water $\left(\mathrm{M}^{3} / \mathrm{t}\right.$ ore $)$ & 1.26 & 1.35 \\
\hline
\end{tabular}

\subsection{Eastern limb strategic opportunity}

To assess the eastern limb production potential various strategic issues were considered. It was first investigated whether global PGM investment is warranted, second, if such production can occur in the national policy framework of South Africa, and third, if development focused on the eastern limb is viable. These conditions focused on geological, mining, economic and other aspects specific to the South African PGM sector. Overall the study indicates that the eastern limb moderately satisfies the conditions for viable production investment. The long-term global need for PGMs supports production. Fortunately South Africa is endowed with the Bushveld Complex and the deposit size, available development pipeline and mining requirements are more than adequately met. Geologically attractive ore bodies are present on the eastern limb that can be successfully exploited and processed. It is possible that new developments could take advantage of shallow resources and new mining techniques to develop low-cost operations. Infrastructural uncertainties are the primary constraints for eastern limb development, being the lowest ranked of all seven criteria. Together with legislative uncertainties the major risks impacting the Bushveld eastern limb are therefore "above-ground" or "non-technical" risks, rather than intrinsic orebody risk (Figure 9).

This study suggests that new PGM mining projects on the eastern limb could be economically superior to new projects on the western limb if long-term availability of water and power can be ensured. A significant 
opportunity is available to South Africa if the eastern limb PGM-related development is tackled by considering the geographical region holistically, compared to the piecemeal approach that has occurred in the western Bushveld. Large tenements are core platforms for future development, especially when contiguous lease areas occur along strike, and down dip. It is suggested that the eastern limb be considered a "mining complex" of clearly delineated regional districts where experience from the western limb can be utilized to develop regional plans underpinned by optimal mine layouts, stope sequencing, and mining methods. Distinction could be made by dividing areas according to each provincial region, thereby supporting local government management. A further example would be studies to predict pothole location and distribution in broad areas using composite data sets to better plan regional mine layouts. Regional plans would be most critical for regional road linkages, power supply, and water reticulation. Such plans could benefit both the public and the mining companies in both economic and social terms.

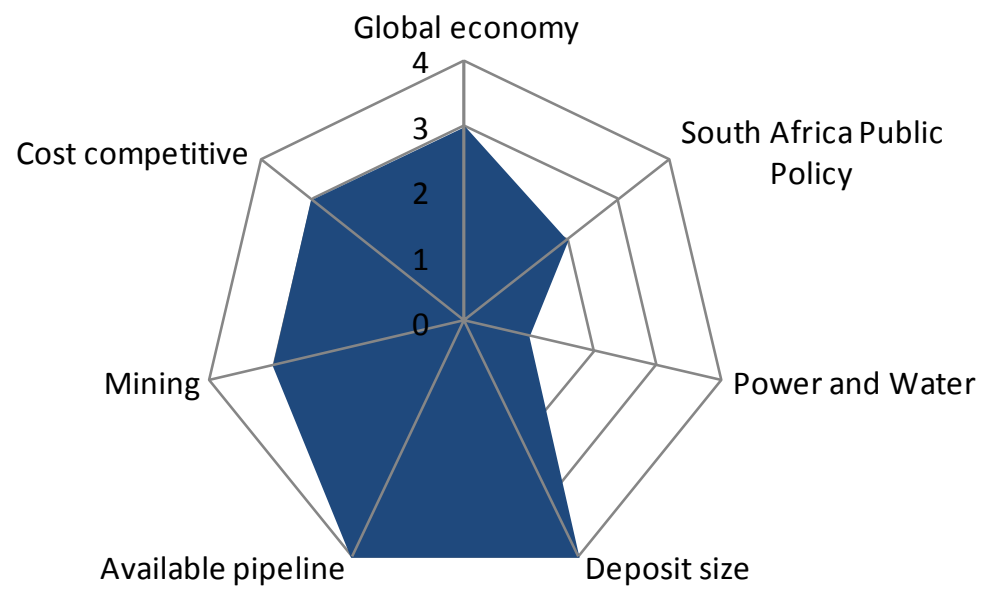

Figure 9 Radar plot of criteria assessment. Total coverage of the area would denote a positive relationship between all criteria and that the eastern limb could be assessed to be favorable for future production. Conversely, open areas are indicative of high-risk components of the system

Extraction of PGMs is required for the foreseeable future. Sufficient exploration activity, feasibility studies, and construction projects are in place on the eastern limb to provide a coherent development pipeline for the future. While certain projects may temporarily be on hold, with improved commodity price forecasts these will probably, once again, move towards completion. Investment potential resides in eastern limb ventures that access near-term PGM reserves at competitive cash costs. Operations that can contain average $4 \mathrm{E}$ cash costs to below $\$ 1,250 / \mathrm{oz}$ will be able to deliver favourable margins going forward. Proposed mining methods should demonstrate a high degree of mechanization, or well managed hybrid mining layouts that optimize face availability. Competitive advantage created by low overall cash-costs is derived by mine specific management teams' expertise and ability to control labour costs. These components should allow for the development of a mining environment that is marginally safer than older operations on the western limb. Impacting the potential of the eastern limb are overriding constraints of limited power and water supplies. While the present situation remains acceptable, increased production on the eastern limb will increase the impact of these constraints. Finally, the political and economic debate regarding mine nationalization increases the degree of uncertainty associated with development of projects on both limbs, and therefore investors should tread with caution until the ruling ANC provides economic policy directives in 2012.

Furthermore these outcomes provide suggestions that policy makers can take into account. This analysis suggests there is currently not a strong driver to favour eastern or western limb development. However, this could change if governmental policy aided in provision of sufficient power and water to eastern limb projects through proactive planning and decision making. Governmental policy could also be utilized to allow for integrated mine development that could result in economically favouring new eastern limb 
projects. The western limb has largely been developed on a mine-by-mine basis with little recognition of synergies between contiguous operations. A strategic advantage available on the eastern limb is for better regional planning. Valuable lessons, to enhance large positive margins, have been learned both from the western limb as well as Witwatersrand gold production. These lessons should be applied to optimize regional development of the eastern limb PGM resources.

\section{Acknowledgements}

The author would first like to thank her academic advisors at the Colorado School of Mines: Dr M. Hitzman; Dr H. Miller; and Dr R. Eggert for their advice and support during the course of this research. Second, the Council for Scientific and Industrial Research (CSIR) in South Africa is acknowledged for their financial support to complete studies at the Colorado School of Mines, and to attend this conference in Western Australia.

\section{References}

Black, W. (2009) Platinum: Platinum junior sector review - third edition, Investec Securities, 81 p.

Butler, J. (2009) Johnson Matthey PLC, Platinum 2009, 61 p.

Butler, J. (2010) Johnson Matthey PLC, Platinum 2010, 61 p.

Butler, J. (2011) Johnson Matthey PLC, Platinum 2011, 61 p.

Cawthorn, R.G., Barnes, S.J., Ballhaus, C. and Malitch, K.N. (2005) Platinum-group element, chromium and vanadium deposits in mafic and ultramafic rocks, in Mafic and Ultramafic rocks in Economic Geology $100^{\text {th }}$ Anniversary Volume, pp. $215-249$.

Cramer, L.A., (2001) The extractive metallurgy of South Africa's platinum ores. JOM, Vol. 53 No. 10, pp. 14-18.

Cramer, L.A., Basson, J. and Nelson, L.R. (2004) The impact of platinum production from UG2 ore on ferrochrome production in South Africa, The Journal of The South African Institute of Mining and Metallurgy, Vol. 104, pp. 517-527.

Deloitte (2011) Tracking the trends: The top 10 issues mining companies will face in the coming year, $17 \mathrm{p}$.

Glaister, B. J. \& Mudd, G. M., 2010, The Environmental Costs of Platinum-PGM Mining and Sustainability: Is the Glass Half-Full or Half-Empty?. Minerals Engineering, 23 (5), pp 438-450.

Gqubule, D. (2010) Overview of mining sector progress in transformation, Mining for Change Summit, unpublished conference paper.

Jacobs, C.A. (2003) Value Creation in Mining: an Analysis of South Africa's Platinum Industry, A research report submitted to the Gordon Institute of Business Science, University of Pretoria, in partial fulfillment of the requirements for the degree of Master of Business Administration, $112 \mathrm{p}$.

Jourdan, P. (2010) The optimization of the developmental impact of South Africa's mineral assets for building a democratic developmental state, Unpublished draft, $73 \mathrm{p}$.

Naldrett, A.J. (2004) Magmatic Sulfide Deposits: Geology, Geochemistry and Exploration, Springer, 728 p.

Steven Forrest Associates (2009) Consultants Report: Bi-annual provision of PGM market intelligence and long-term metal price forecasts, Working Draft, $206 \mathrm{p}$.

Singh, N., Urcan, H., Naidoo, K., Ryder, J., Watson, B.P., Milev, A.M. and Roberts, M.K.C. (2005) The influence of pillars on the Merensky Reef horizon on stoping operations on the underlying UG2 Reef horizon, The Journal of The South African Institute of Mining and Metallurgy, Vol. 105, pp. 427-436.

Van der Zwan, P. (2010) Getting to the bottom of South Africa's new mining royalties, Accounting South Africa, viewed 5/7/2010, www.accountancysa.org.za/resources. 